\title{
THE EFFECT OF FILTER-PRESS CAKE ON THE PHYSICAL AND CHEMICAL PROPERTIES OF SOILS ${ }^{1}$
}

\author{
M. A. Lugo-López, E. Hernández-Medina, H. R. Cibes-Viadé and \\ $J$. Vicente-Chandler ${ }^{2}$
}

\section{INTRODUCTION}

The growing appreciation of the beneficial effects of filter-press cake upon crop yields has led to a number of theories concerning the mechanisms involved. Some are of the opinion that filter-press cake promotes better plant growth and production through the release to plants of some unidentified organic growth regulator. Others believe that it raises and balances the fertility level of the soil through the release of nitrogen, potash, and other plant nutrients. Still others feel that it is through their effect on the physical properties of soils as a medium for plant growth that filter-presscake applications result in heavier crop yields. In all probability increased crop yields are the resultant of all three mechanisms or at least of the last two: Beneficial effect on the fertility level and on the physical properties of soils.

The literature concerning the use of filter-press cake in agriculture is very limited. Although a number of reports have appeared sporadically during the past decade, most of them have been merely the results of random observations unfortified by experimental evidence.

Early experimental work at Río Piedras indicated that an application of 20 tons to the acre of filter-press cake increased yields of cucumbers (1) ${ }^{3}$, Hernández-Medina $(4,5,6)$ reported that pineapple plants grown in pots filled with soil the top 4 or 6 inches of which had been mixed with filterpress cake, developed vigorously and were of a dark-green color. Their leaves were wider and their steams and flowers stalks thicker than those given other treatments. Furthermore, they were the heaviest yielders of fruit and produced the largest number of slips and suckers per plant.

Work under field conditions in the Arecibo coastal area has shown that,

${ }_{1}$ This paper constitutes the fourth in a series on the same general subject, the first and second of which will be found in the Journal of Agriculture 36 (3) 255-301 1952 , and the third in this issue of the Journal, pp. 206-12.

${ }^{2}$ Associate Soil Scientist, Assistant Plant Physiologist, Associate Plant Physiologist, and Acting Supervisor Cooperative Bureau of Plant Industry Research Unit, Agîicultural Experiment Station, University of Puerto Rico, Rio Piedras, P. R. Appreciation is expressed to J. A. Bonnet, who provided some of the data on the chemical composition and production of filter-press cake. Olga V. Rivera, Carmen Laura R. Kreil and S. Silva cooperated in the laboratory work, and H. Gandía and $R$. Olivencia in the sampling of the Corozal field.

${ }^{3}$ Numbers in parentheses refer to Literature Cited, pp. 222-3. 
when filter-press cake is applied to the soil at the rate of 32 tons to the acre, maximum yields of pineapple can be obtained with applications of a 12-6-10 fertilizer at the rate of only 1,500 pounds to the acre. At Corozal, however, both heavy applications of filter-press cake (32 tons) and of fertilizer (3,000 pounds) were necessary for obtaining maximum yields (7).

This paper reports on the soil conditions at the two sites where the latest field experiments were conducted by Hernández-Medina, et al. (7). It presents data on the physical and chemical properties of soils which received different quantities of filter-press cake, about 18 months after establishing the treatment differentials.

\section{NATURE AND PROPERTIES OF FILTER-PRESS CAKE}

Filter-press cake or filter-press mud is a byproduct from the sugar mills. It is generally obtained in Puerto Rican mills from Oliver and press filters.

TABLE 1.-Production of filter-press cake per ton of cane and polarization values obtained from 4 sugar mills in east-central Puerto Rico, $1952^{1}$

\begin{tabular}{|c|c|c|}
\hline Mill & $\begin{array}{l}\text { Filter-press cake per ton } \\
\text { of cane }\end{array}$ & Polarization \\
\hline & Percent & Degrees \\
\hline Juncos . . . . & 2.91 & 3.681 \\
\hline Pasto Viejo . . . . . . . . . . . . . . . & 2.36 & 4.194 \\
\hline Santa Juana. .................... & 3.57 & 2.380 \\
\hline Cayey.......................... & 2.84 & 5.567 \\
\hline
\end{tabular}

${ }^{1}$ Personal communication from Mr. M. A. del Valle, President and General Manager of the Eastern Sugar Associates, to Dr. J. A. Bonnet, Head, Soils Department, Agricultural Experimental Station, University of Puerto Rico, Sept. 5, 1952.

It is a soft, spongy, lightweight, amorphous material that can absorb rather large quantities of water when dry. As obtained from the mills it generally contains between 60 to 80 percent of moisture and 2 to 4 percent of sucrose. The mean production of filter-press cake is estimated to range from 1.25 percent to over 3.00 percent of the weight of the cane. On the basis of $12,000,000$ tons of millable cane per year, the annual production of filterpress cake should range from 150,000 to 360,000 tons. Table 1 gives data on the production of filter-press cake per ton of cane for four sugar mills in east-central Puerto Rico.

Table 2 gives the range of values for the chemical composition of various samples of filter-press cake taken from a number of sources. Some of the samples were obtained from the South Puerto Rican Sugar Co. in southern Puerto Rico, others from mills in the east-central region, and others from the northern region. Compared to a commercial fertilizer, filter-press cake is low in nutrient content. However, as compared with a soil, it is rather 
high in organic matter and nutrients. It contains somewhat less moisture than fresh animal manures, but is much higher in nitrogen and phosphoric acid. It can probably supply about the same potash as horse and cow manures (9).

As a fertilizer filter-press cake must be rated as rather low in nutrients and somewhat unbalanced. Consideration must also be given to the decomposition processes that follow its application to the soil. In usual farm practice, because of the large quantities of filter-press cake applied per unit area (anywhere from 15 to 100 tons to the acre), relatively large quantities of total nutrients are actually added to the soil.

Moreover, large quantities of rather stable organic matter are actually added to the soil when incorporating filter-press cake. The unquestionable benefits of organic matter, not merely from the standpoint of soil fertility, sut as a soil conditioner as well, have often been observed. Field observa-

TABLE 2.-Range in chemical composition of filter-press cake from various sources

\begin{tabular}{|c|c|c|c|c|}
\hline Constituent & Range of values & & Constituent & Range of values \\
\hline & Percent & & & Percent \\
\hline Moisture....... & $60-80$ & $\mathrm{~K}_{2} \mathrm{O}$. & & $0.46-0.89$ \\
\hline Organic matter. . & $20-30$ & $\mathrm{CaO}$. & & $3.11-4.13$ \\
\hline Sucrose . . . . . . . & $2-4$ & $\mathrm{MgO}$. & & 2.38 \\
\hline Nitrogen . . . . . & $0.94-1.31$ & $\mathrm{Fe}_{2} \mathrm{O}_{3}$ & and $\mathrm{Al}_{2} \mathrm{O}_{3} \ldots \ldots$ & 1.70 \\
\hline $\mathrm{P}_{2} \mathrm{O}_{5} \ldots \ldots \ldots$ & $1.66-2.74$ & & & \\
\hline
\end{tabular}

tions indicate that, when applied in large quantities to heavy soils, structural conditions are improved; water retention at low tensions is generally increased in light-texture soils with low organic-matter contents.

\section{MATERIALS AND MFTHODS}

Two fields were selected, one at Palo Blanco, Arecibo, in northern Puerto Rico, and one at the farm of the Corozal Agricultural Substation, in the interior. At Arecibo, the soil has been classified as Bayamón silty clay, an acid, deep, lateritic soil of the coastal plains derived from limestone. At Corozal, the soil is a typical, nearly level Lares clay, a medium-friable soil occurring in terrace formations and derived from material washed from the lower Tertiary clays and shales.

- A detailed account of all the field operations concerning the soil- and crop-management techniques employed during the course of the experiment has been reported elsewhere (7). For the objectives of the investigation herein reported soil samples were taken some 18 months after establishing the treatment differentials. Samples were taken only from the plots treated 
as follows: ${ }^{4}$

Treatment B: 16 tons of filter-press cake and 1,500 pounds of a 12-6-10 fertilizer to the acre.

Treatment D: 32 tons of filter-press cake and 1,500 pounds of a 12-6-10 fertilizer to the acre.

Treatment L: No filter-press cake, 3,000 pounds of a 12-6-10 fertilizer to the acre.

Bulk soil samples to a depth of 6 inches were taken both at the Arecibo and Corozal experimental fields. At the latter location, undisturbed soil cores were also taken from the 1- to 4 -inch layer of soil by using a special sampler of the Bradfield type, 3 inches in diameter by 3 inches in length.

Permeability measurements were made in undisturbed soil cores by recording the rate at which water moved through a column of saturated soil at a known head. Quick drainage was determined by placing the soil core in a Büchner funnel, setting a $60-\mathrm{cm}$. tension, and measuring the water drained out at the end of 15 minutes. The water retained at $\mathrm{pF} 1.78$ was measured by bringing the soil core to equilibrium with a $60-\mathrm{cm}$. tension and determining the variation in weight of the core. Water remaining at pF's 2.7 and 4.2 was determined by submitting saturated soil samples to pressures of 0.5 and 15 atmospheres, respectively, in special pressure plates. The maximum saturation was calculated from the above data. The available water was considered to be in the range between $\mathrm{pF} 1.78$ and $\mathrm{pF} 4.2$.

The soil core was finally dried in the oven at $110^{\circ} \mathrm{C}$. As the samples used had a definite known volume, the bulk density of the soil was calculated by dividing the net dry weight of soil by its original volume. The pore space was then calculated by assuming a specific gravity value of 2.65 . The air porosity was considered to be the difference between total porosity and water porosity (water retained at $\mathrm{pF} 1.78$ ).

The $\mathrm{pH}$. was determined electrometrically by means of a Macbeth $\mathrm{pH}$ meter. Total nitrogen was determined by the standard Kjeldahl method and the organic matter by the chromic acid titration method. The carbonnitrogen ratio was subsequently calculated from the above data. The exchange capacity was determined by the ammonium acetate method. Exchangeable calcium, magnesium, and manganese were determined by methods developed by Peech (11). Available phosphorus and iron in the soil were extracted with Morgan universal solution as described by Bonnet and Riera (2). Phosphorus was then determined colorimetrically by the procedure developed by Wolfe (12), and iron by the method of Saywell and Cunningham, as described by Parks, et. al. (10).

${ }^{4}$ For a detailed description of each treatment see Hernández-Medina, E., et al. The beneficial effect of filter-press cake on pineapple yields under field conditions, J. Agr. Univ. of P. R. 37 (3) 206-12 1953. 


\section{RESULTS AND DISCUSSION}

The results of the chemical analyses of the soils taken from the Arecibo and Corozal filter-press cake experimental fields are shown in tables 3 and 4. At Arecibo the range of $\mathrm{pH}$ values for all plots was from 4.1 to 5.6 with a mean of $\mathrm{pH} 4.6$ for soils under all treatments combined. There were no significant differences between the means of the treatments. At Corozal there was a narrower range of variation considering all plots, but the $\mathrm{pH}$

TABLE 3.-Mean $p H$, nitrogen, organic matter, and $C / N$ ratio of soils from the filter-press cake experimental fields at Arecibo and Corozal

\begin{tabular}{|c|c|c|c|c|c|c|}
\hline \multirow{2}{*}{$\begin{array}{c}\text { Treatment } \\
\text { identification letter }\end{array}$} & \multicolumn{2}{|c|}{ Description of soil treatments } & \multirow{2}{*}{$\mathrm{pH}$} & \multirow{2}{*}{ Nitrogen } & \multirow{2}{*}{$\begin{array}{l}\text { Organic } \\
\text { matter }\end{array}$} & \multirow{2}{*}{$\mathrm{C} / \mathrm{N}$ ratio } \\
\hline & $\begin{array}{l}\text { Filter-press } \\
\text { cake }\end{array}$ & $\begin{array}{c}\text { Fertilizer } \\
12-6-10\end{array}$ & & & & \\
\hline
\end{tabular}

Results at Arecibo ${ }^{1}$

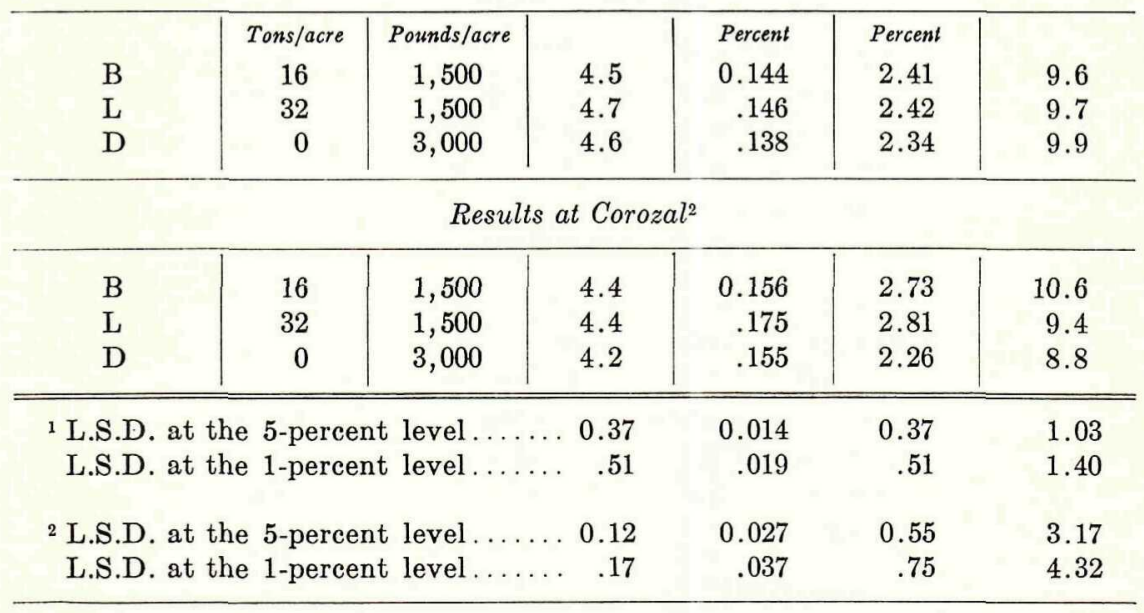

of the plots receiving either 16 or 32 tons of filter-press cake to the acre was significantly higher than that of the control plots. The mean nitrogen content of soils under all combined treatments was 0.142 for Arecibo and 0.162 for Corozal. There were no significant differences between the mean nitrogen content of soils of the plots to which filter-press cake was added and those which did not receive additional organic matter. The differential application of fertilizer to these plots may account for the apparent uniformity in spite of the organic material added to some of them.

Although no significant differences could be measured statistically in the organic-matter content of the plots receiving 0,16 , and 32 tons of filterpress cake to the acre, organic-matter levels were consistently lower on all 
plots to which no filter-press cake was added than on those which received either 16 or 32 tons of the filter-press cake. The differences are particularly noticeable at Corozal. Data in table 2 indicate that filter-press cake has a rather wide $\mathrm{C} / \mathrm{N}$ ratio of about $50: 1$. By the time it becomes an integral part of the soil, this ratio must be narrowed down to 10:1.

Assuming a moisture content of 70 percent, 16 tons of filter-press cake can become 0.96 ton of organic matter with a $\mathrm{C} / \mathrm{N}$ ratio of $10: 1$, which is

TABLE 4.-Total exchange capacity; exchangeable calcium, magnesium, and manganese; and available phosphorus and iron for soils from the filter-press cake experimental fields at Arecibo and Corozal

\begin{tabular}{|c|c|c|c|c|c|c|c|}
\hline \multirow{2}{*}{$\begin{array}{l}\text { Treatment } \\
\text { identifica- } \\
\text { tion letter }\end{array}$} & \multicolumn{2}{|c|}{$\begin{array}{l}\text { Description of soil } \\
\text { treatments }\end{array}$} & \multirow{2}{*}{$\begin{array}{l}\text { Total } \\
\text { exchange } \\
\text { capacity }\end{array}$} & \multicolumn{2}{|c|}{ Exchangeable cations ${ }^{1}$} & \multirow{2}{*}{$\begin{array}{l}\text { Available } \\
\text { phosphorus }\end{array}$} & \multirow{2}{*}{$\underset{\substack{\text { Available } \\
\text { iron }}}{0}$} \\
\hline & $\begin{array}{c}\text { Filter- } \\
\text { press cake }\end{array}$ & $\begin{array}{c}\text { Fertilizer } \\
12-6-10\end{array}$ & & Calcium & Magnesium Manganese & & \\
\hline
\end{tabular}

Results at Arecibo

\begin{tabular}{|c|c|c|c|c|c|c|c|c|}
\hline & Tons/acre & Pounds/acre & M.e. & M.e. & M.e. & M.e. & Percen! & Percent \\
\hline$B$ & 16 & 1,500 & $8.1^{2}$ & 1.75 & 0.01 & 0.30 & 0.0005 & 0.0004 \\
\hline $\mathrm{D}$ & 32 & 1,500 & $8.3^{2}$ & 1.15 & .03 & .24 & .0005 & .0004 \\
\hline L & 0 & 3,000 & $8.2^{2}$ & 1.68 & .02 & .33 & .0005 & .0005 \\
\hline \multicolumn{9}{|c|}{ Results at Corozal } \\
\hline B & 16 & 1,500 & $12.6^{3}$ & 2.54 & 0.33 & 0.18 & 0.0006 & 0.0016 \\
\hline $\mathrm{D}$ & 32 & 1,500 & $12.1^{3}$ & 2.12 & .14 & .31 & .0005 & .0012 \\
\hline $\mathrm{L}$ & 0 & 3,000 & $12.8^{3}$ & 1.08 & .02 & .47 & .0005 & .0012 \\
\hline
\end{tabular}

${ }^{1}$ Expressed as m.e. per $100 \mathrm{gm}$. of dry soil

${ }^{2}$ L. S. D. at the 5-percent level 1.16

L. S. D. at the 1-percent level 1.58

${ }^{3}$ L. S. D. at the 5 -percent level 0.67

L. S. D. at the 1-percent level .92

equivalent to 0.096 percent of organic matter in the plow layer. Applications of 32 tons of moist filter-press cake would be equivalent to twice as much organic matter. The decomposition of filter-press cake, like any other organic residue, must be rather rapid under the conditions of the Tropics. Therefore, in spite of the seemingly large additions of organic matter in the $\mathrm{B}$ and $\mathrm{D}$ treatments, as contrasted with the $\mathrm{L}$ treatments, the accumulated differences were not significant.

The mean $\mathrm{C} / \mathrm{N}$ ratios were between 9.6 and 9.9 at Arecibo, and between 8.3 and 10.6 at Corozal. The differences were not significant. All these ratios considered together were rather narrow, which indicates that the filter-press cake decomposes rapidly under the action of the soil micro-organisms. No 
wide $\mathrm{C} / \mathrm{N}$ ratios indicative of slow decomposition, were observed. However, it must be remembered that the plots to which filter-press cake had been added received 1,500 pounds to the acre of a 12-6-10 fertilizer, which insured an adequate supply of nitrogen for both micro-organisms and plants during the early critical stages of crop growth.

Table 4 gives mean values for total exchange capacity; exchangeable calcium, magnesium, and manganese; and available phosphorus and iron for the soils from the Arecibo and Corozal experiments. The mean total exchange capacity of all the plots was 8.2 m.e. and 12.5 m.e. for the Arecibo and Corozal experiments, respectively, with very small deviations above or below.

The soils are very low in calcium (less than 25 percent) and magnesium saturation at both locations. In general, they are high in manganese and low in available phosphorus and iron. Under the conditions that prevail in Corozal, applications of 16 and 32 tons to the acre of filter-press cake increased the exchangeable calcium and magnesium and decreased the exchangeable manganese; but did not affect the available phosphorus and iron of the soil. At Arecibo, none of the elements considered were apparently affected.

As shown in table 5, the soils receiving filter-press cake-applications seemed to have a larger capacity to retain water at low tensions ( $\mathrm{pF}$ 1.78) than the soils otherwise treated. This water is readily available and the plants can remove it quickly until tensions in the vicinity of the permanent wilting percentage $(\mathrm{pF} 4.2)$ develop. The retention of moisture at $\mathrm{pF} 4.2$ tends to be lower in the plots treated with filter-press cake. Thus in all probability, they can supply more available water for crop growth than plots otherwise treated. Continued treatments over a period of years may result in larger accumulations of soil organic matter and consequently in greater moisture-supplying power. This may have a bearing upon crop yields. There were no outstanding differences in permeability, quick drainage, and maximum saturation in the soils of Corozal undergoing the various filter-press cake treatments.

Table 6 presents data on bulk density, total porosity, and air porosity of soils taken from the plots undergoing the various filter-press-cake treatments. Bulk-density values average $1.19 \mathrm{gm}$./ce., with very small deviations above or below. The mean porosity of all plots, irrespective of treatments, was 54.7. The air porosity was in inverse relationship to the water porosity (water retained at $\mathrm{pF} 1.78$ ), the total pore space being more or less constant.

The results of these investigations are not conclusive by any means. It remains to be proved beyond doubt that the increased yields reported to be attributable to filter-press cake applications $(1,4,5,6,7)$ are the reflection of the effect of the treatments upon soil conditions. The incorporation of 
large quantities of organic matter in a continuous steady way for a number of years has been shown to produce a better state of aggregation and consequently the formation of a larger proportion of macroaggregates capable of holding considerable quantities of water at relatively low tensions. The

TABLE 5.-Permeability and other soil-moisture data gathered from soil cores collected from the filter-press-cake experimental field at Corozal

\begin{tabular}{|c|c|c|c|c|c|c|c|c|c|}
\hline \multirow{2}{*}{$\begin{array}{l}\text { Treatment } \\
\text { identifica- } \\
\text { tion letter }\end{array}$} & \multicolumn{2}{|c|}{$\begin{array}{l}\text { Descriptionof soil } \\
\text { treatments }\end{array}$} & \multirow{2}{*}{$\begin{array}{l}\text { Permea- } \\
\text { bility }\end{array}$} & \multirow{2}{*}{$\begin{array}{l}\text { Water } \\
\text { drained at } \\
60 \mathrm{cms} \text {. in } \\
15 \text { minutes }\end{array}$} & \multirow{2}{*}{$\begin{array}{l}\text { Maximum } \\
\text { saturation }\end{array}$} & \multicolumn{3}{|c|}{ Water retained at $\mathrm{pF}$ of -} & \multirow{2}{*}{$\begin{array}{c}\text { Available water } \\
\text { (water at pF } \\
\text { 1.78-water at } \\
\text { pF 4.2) }\end{array}$} \\
\hline & $\begin{array}{l}\text { Filter- }- \\
\text { press } \\
\text { cake }\end{array}$ & $\mid \begin{array}{c}\text { Fertilizer } \\
12-6-10\end{array}$ & & & & 1.78 & 2.7 & 4.2 & \\
\hline & $\begin{array}{l}\text { Tons/ } \\
\text { acre }\end{array}$ & $\begin{array}{l}\text { Pounds/ } \\
\text { acre }\end{array}$ & $\begin{array}{l}\text { Inches/ } \\
\text { hour }\end{array}$ & Percenl & Percent & Percent & Percent & Percent & Percent \\
\hline B & 16 & 1,500 & 12.9 & 8.1 & 54.9 & 40.0 & 35.4 & 23.5 & 16.5 \\
\hline $\mathrm{D}$ & 32 & 1,500 & 22.7 & 8.1 & 53.7 & 39.6 & 32.2 & 24.5 & $15.1^{\circ}$ \\
\hline L & 0 & 3,000 & 32.4 & 12.6 & 55.8 & 36.3 & 33.6 & 26.2 & 10.1 \\
\hline
\end{tabular}

L.S.D. at the 5-percent level .............. L.S.D. at the 1-percent level ..............

$\begin{array}{rrrrrrr}31.9 & 7.1 & 4.0 & 5.3 & 3.8 & 3.6 & 5.8 \\ 45.8 & 10.2 & 5.8 & 7.5 & 5.0 & 5.1 & 8.3\end{array}$

TABLE 6.-Bulk density, pore space, and air porosity of soils from the filler-press-cake experimental field at Corozal

\begin{tabular}{|c|c|c|c|c|c|}
\hline \multirow{2}{*}{$\begin{array}{l}\text { Treatment } \\
\text { identification } \\
\text { letter }\end{array}$} & \multicolumn{2}{|c|}{ Description of soil treatments } & \multirow{2}{*}{ Bulk density } & \multirow{2}{*}{ Total pore space } & \multirow{2}{*}{$\begin{array}{c}\text { Air porosity } \\
\text { (total pore space- } \\
\text { water at pF } \\
1.78 \text { ) }\end{array}$} \\
\hline & Filter-press cake & Fertilizer $12-6-10$ & & & \\
\hline & Tons/acre & Pounds/acre & $\mathrm{Gm} \cdot / \mathrm{cc}$. & Percent & Percent \\
\hline $\mathrm{D}$ & 16 & 1,500 & 1.21 & 54.5 & 14.5 \\
\hline B & 32 & 1,500 & 1.18 & 54.5 & 14.9 \\
\hline $\mathrm{L}$ & 0 & 3,000 & 1.19 & 55.2 & 18.9 \\
\hline \multirow{2}{*}{\multicolumn{3}{|c|}{$\begin{array}{l}\text { L.S.D. at the } 5 \text {-percent level . . } \\
\text { L.S.D. at the } 1 \text {-percent level . . }\end{array}$}} & 0.07 & 2.4 & 7.1 \\
\hline & & & .10 & 3.5 & 10.1 \\
\hline
\end{tabular}

work of Lugo-López, Landrau, and Samuels (8) with sugarcane trash substantiates this fact. Browning and Milán (3) have observed significant increases in aggregation with each unit increase in organic matter. Perhaps the influence of filter-press cake upon soil conditions can be measured in a clear-cut way after several years of continuous treatments.

In Puerto Rico the yearly production of filter-press cake has been estimated to fluctuate between 150,000 and 360,000 tons. The following tabulation indicates the extent to which filter-press cake was used in $1951 .{ }^{5}$

${ }^{5}$ Personal communication by Alcides Zeno, Chief, ACP and District Officer Di- 


\begin{tabular}{lccc} 
Filter-press cake applied to cane lands & Tons & Benefit payment \\
Filter-press cake applied to other lands & 136,211 & & $\$ 68,105$ \\
Total & 113,767 & & 113,768 \\
\cline { 2 - 2 } & & & $\$ 181,873$
\end{tabular}

The benefit payments of the Production and Marketing Administration have greatly enhanced the use of filter-press cake on the farm. More than half of the filter-press cake obtained is applied to sugarcane fields, mostly new plantings. The rate of applications varies from 15 to almost 100 tons to the acre. However, with the large bulk of trash available in sugarcane fields there is hardly any need for additional organic-matter sources (8). The emphasis should be shifted towards applications of filter-press cake to other crops such as pineapple, truck crops, and so on.

\section{- SUMMARY}

Data are presented here on soil conditions at the Arecibo and Corozal filter-press-cake experimental fields 18 months after establishing the treatment differentials. The experiments were located on a Bayamón silty clay and a Lares clay, respectively, both representative of the group of soils generally used for growing pineapples in the northern and interior districts of the Island.

A previous report indicated that maximum yields of pineapple in the Arecibo region could be obtained with applications of 1,500 pounds to the acre of a 12-6-10 fertilizer, if applications of filter-press cake were made at the rate of 32 tons to the acre. At Corozal, however, both heavy applications of filter-press cake (32 tons) and of fertilizer (3,000 pounds) were necessary for obtaining maximum yields.

Soil samples were taken from the top 6 inches at both locations and analyzed for $\mathrm{pH}$, nitrogen, organic matter, total exchange capacity, exchangeable calcium, magnesium, and manganese, and available phosphorus and iron. In addition, undisturbed soil cores were taken at Corozal and data were gathered on the permeability, rapidity of drainage, maximum saturation, water retained at various tensions, porosity, and bulk density.

Although no significant differences were obtained in most cases, some trends were observed, such as the retention of larger quantities of available moisture at low tensions in a state of ready availability for plants by soils to which filter-press cake was added than by those to which only fertilizer was applied. The $\mathrm{C} / \mathrm{N}$ ratios were narrow in all cases, indicative of quick dêcomposition of the organic residues after application.

vision, Production and Marketing Administration, U.S.D.A., to J. A. Bonnet, Head, Soils Department, Agricultural Experiment Station, University of Puerto Rico, Sept. 4, 1952. 


\section{RESUMEN}

Se presentan aquí datos sobre las propiedades del suelo en los campos experimentales de Arecibo y Corozal 18 meses después de haber tratado parcelas con dos niveles de cachaza y haber dejado parcelas testigos sin recibir cachaza. Los experimentos se localizaron en suelos de Bayamón limoarcilloso y Lares arcilloso, ambos representativos de los suelos donde generalmente se cultiva la piña en las zonas norte e interior de la Isla. En un informe previo se presentó evidencia que indicaba que se podían obtener rendimientos máximos de piña en la zona de Arecibo con aplicaciones de 1,500 libras de abono 12-6-10 si se habían hecho aplicaciones de cachaza previamente a razón de 32 toneladas por acre. En Corozal, sin embargo, es necesario aplicar 32 toneladas de cachaza y 3,000 libras de abono por acre para poder lograr rendimientos máximos de piña.

En ambas localidades se tomaron muestras de las primeras pulgadas del suelo y se determinó el $\mathrm{pH}$, contenido de nitrógeno, materia orgánica, capacidad total de intercambio, calcio, magnesio y manganeso intercambiable, y fósforo e hierro asimilables.

En Corozal se tomaron además, columnas de suelo en su estado natural y se midió la permeabilidad, agua removida en 15 minutos a una tensión de 60 centímetros, saturación máxima, humedad retenida a varias tensiones, porosidad y densidad aparente del suelo.

Aunque no se obtuvieron diferencias significativas atribuíbles a los tratamientos en la mayoría de los casos, se observaron tendencias de importancia, tales como mayor retención de humedad aprovechable en los suelos que recibieron aplicaciones de cachaza en contraste con los que sólo recibieron abono químico.

La razón de carbono a nitrógeno fué estrecha en todos los casos, indicando que la descomposición de la materia orgánica fué rápida.

\section{LITERATURE CITED}

1. Annual Report, 1937-38, Agr. Exp. Sta., Univ. P. R. pp. 84-85, 1938.

2. Bonnet, J. A., and Riera, A. R., Tracing the mineral from the soil to the plant to the animal blood: I, Effect of lime on the mineral composition of the soil, of the grass, and on the crop yield, J. Agr. Univ. P. R. 30 (3) 138-58 1946.

3. Browing, G. M. and Milan, F. M., Rate of application of organic matter in relation to aggregation, Soil Sci. Soc. Amer. Proc. 6 95-7 1941.

4. Hernández-Medina, E., The beneficial effect of filter-press cake on pineapple growth, development, and production: I, Effect on the plant crop, J. Agr. Univ. P. R. 36 (3) 255-80 1952.

5. Hernández-Medina, E., The beneficial effect of filter-press cake on pineapple growth, development, and production: II, Effect on the ratoon crop, J. Agr. Univ. P. R. 36 (3) 281-301 1952.

6. Hernández-Medina, E., Filter-press cake increases pineapple yields in Puerto Rico, Agr. Exp. Sta. Univ. P. R. Bull. 1041952. 
7. Hernández-Medina, E., Lugo-López, M. A., and Cibes-Viadé, H. R., The beneficial effect of filter-press cake on pineapple yields under field conditions, $J$. Agr. Univ. P. R. 37 (3) 206-12 1953.

8. Lugo-López, M. A., Landrau, Jr., P., and Samuels, G., The handling of sugarcane trash; II, Effect of various practices on soil properties, J. Agr. Univ. P. R. 36 (3) 246-54 1952.

9. Lyon, T. L., and Buckman, H. O., The nature and properties of soils, 5 th edition, revised, Macmillan Co., New York, N. Y., p. 410, 1943.

10. Parks, R. Q., Hood, S. L., Hurvitz, C., and Allis, G. H., Quantitive chemical microdetermination of twelve elements in plant tissue, a systematic procedure, Ind. Eng. Chem. Anal. 15 (8) 527-33 1943.

11. Peech, M., Determination of exchangeable bases in soils, Ind. Eng. Chem. Anal. 13 (6) 436-41 1941.

12. Wolf, B., Rapid determination of soluble nutrients in soil and plant extracts by means of a photoelectric colorimeter, Ind. Eng. Chem. Anal. 15 248-51 1953. 